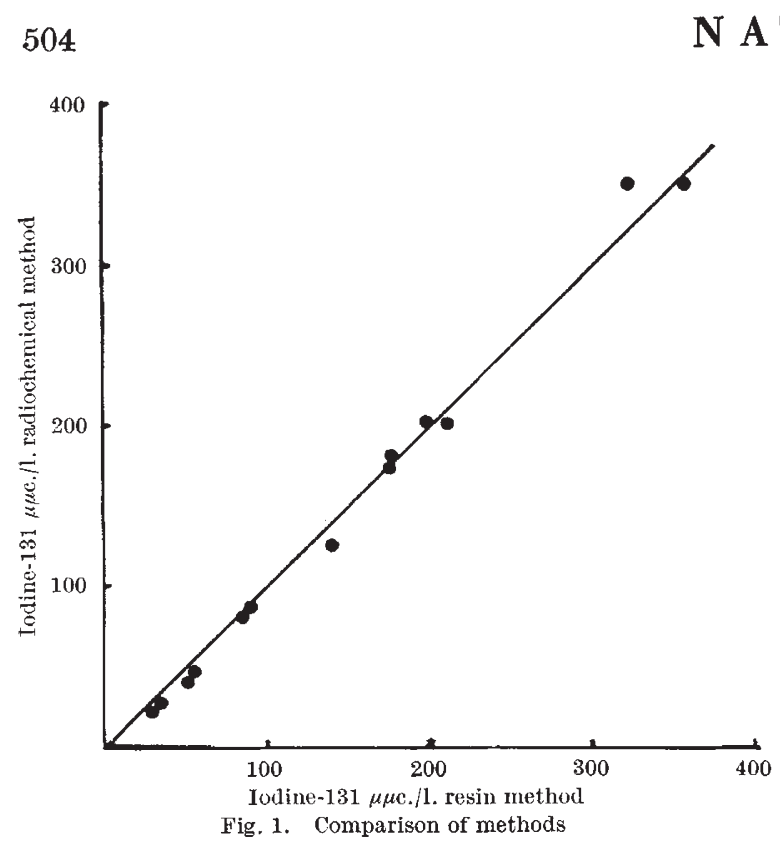

this time the iodine-131 concentration in milk was about $100 \mu \mu \mathrm{c} . / \mathrm{l}$. as a result of fall-out from weapon testing. Radiochemical analysis of the ultrafiltrate and residue indicated that 60 per cent of the iodine-131 was present in the ultrafiltrate. Samples of the original milk were then passed through an anion exchange resin column. Duplicate analysis showed 100 per cent retention of iodine-131 by the resin. From this we concluded that radioactive iodine complexed with protein was quantitatively removable by resin treatment.

Details of our experimental technique for the estimation of iodine-131 in milk are:

$50 \mathrm{ml}$. of wet 'Deacidite $F F^{\prime}, 3-5$ per cent cross-linking (SRA 63) 14-52 mesh in the chloride form, are transferred to a column of dimensions $25 \mathrm{~cm} \times 1.5 \mathrm{~cm}$. One litre of fresh milk is then passed through the column at a flowrate of $5 \mathrm{ml} . / \mathrm{min}$. On completion the resin is blown out of the column into a clean beaker using compressed air, washed twice by decantation with $100 \mathrm{ml}$. demineralized water and transferred to a polystyrene container $(6 \cdot 5 \mathrm{~cm}$ diam. $\times 2 \mathrm{~cm}$ high) which fits on top of a sodium iodide crystal. We have shown that this washing procedure causes no loss of activity. Indeed, the resin can be acotonewashod and air-dried without any measurable loss. The iodine-131 content is determined in a $\gamma$-spectrometer using the $0.364 \mathrm{MeV}$ photopeak. With a 3 in. $\times 3$ in. sodium iodide ( $\mathrm{Tl}$ activated) crystal, the detection limit is $10 \mu \mu \mathrm{c}$. with $\approx$ precision of 15 per cent if counting is for $50 \mathrm{~min}$.

Because of our success in removing iodine-131, we com. pared the reproducibility of the method to our standard radiochemical procedure ${ }^{7}$ after spiking milk with iodine131 in the ionic form. Details are given in Fig. 1.

Our technique agroos well with that described by Boni ${ }^{8}$, and we have found the method reliable over a period of several months.

H. SмIтH

E. L. WHITEHEAD

U.K. Atomic Energy Authority,

Production Group,

Chapelcross Works,

Annan,

Dumfriesshire.

${ }^{1}$ Cosslett, P., and Watts, R. E., AERE-R-2881 (1959).

${ }^{2}$ Lengemann, F. W., and Swanson, E. W., J. Dairy Sci., 40, 216 (1957).

3 Garner, R. J., Paper presented at a conference on The Passage of Fission Products through Food Chains (AERE, Harwell, 1958).

4 Morgan, A., J. Dairy Res., 27, 399 (1960).

${ }^{5}$ Glascock, R. F., J. Dairy Res., 21, 318 (1954).

- Wright, W. E., Christian, J. E., and Andrews, F. N., J. Dairy Sci., 38 , 131 (1955).

7 Technical Manager (Chemistry), P.G. Report 204(W).

${ }^{\circ}$ Boni, A. L., Analyst, 88, 64 (1963).
August 3, 1963 vol. 199

\section{Splitting of Uracil Dimer by High-energy Electrons}

Thymine or uracil in frozen aqueous solutions are readily converted into their dimers by ultra-violet irradiation $^{1-3}$. Using ion exchange chromatogxaphy on 'Dowex ${ }^{\prime}$ ', the dimers of both pyrimidines-2-14 $\mathrm{C}$ were prepared in chromatographic homogeneous forms. Recently, it was established by us that thymine dimer is easily split into thymine monomer by irradiation with high-energy electrons ${ }^{4}$.

During the experiments recorded here an aqueous solution of uracil dimer $(120 \mu \mathrm{g} / \mathrm{ml}$.) was irradiated with $100 \mathrm{kr}$. electrons of $34 \mathrm{MeV}$ at room temperature. After exposure to $\beta$-rays 30 per cent of the radioactivity of the uracil labelled with carbon-14 were shown to be situated in monomer uracil by the method of paper chromatography. By the same dose of $200 \mathrm{kV}$ X-rays the splitting effect could not be found at this high quantity, while the damages of the monomer molecules rose significantly. Similar results have recently been published for $\mathrm{X}$-irradiation of thymine dimer ${ }^{5}$.

The easy splitting of thymine dimer may be of some biological importance in connexion with the restoration of damaged cells. Dimerization of pyrimidines in the nucleic acid chain is also believed by some authors to cause lethal or mutagenic effects by ultra-violet irradiation $^{1,6}$. Therefore, several experiments were carried out on the reactivation of ultra-violet irradiated bacteria, and our preliminary results indicate a rise in survival of ultra-violet irradiated bacteria after irradiation with low doses of electrons.

\section{B. SCHMIDT \\ D. HARTMANN \\ K. Grossgebauer \\ W. Schumacher}

Institut für Hygiene und Medizinische Mikrobiologie, Freie Universität, Berlin, und

Abteilung für Strahlentherapic und Nuklearmedizin des Städtischen Rudolf-Virchow-Krankenhauses, Berlin.

1 Rörsch, A., Beukers, R., Ijlstra, J., and Berends, W., Recueil. Trav, chin . Pays-Ras, yo, 423 (1958).

${ }^{2}$ Beukers, R., and Berends, W., Biochim. Biophys. Acta, 41, 550 (1960). ${ }^{3}$ Wacker, A., Träger, L., and Weinblum, D., Angew. Chemie, 73, 65 (1961). ${ }^{4}$ Schmidt, B., Hartmann, D., Grossgebauer, K., and Schumacher, W., Naturwise., 50, 473 (1963).

${ }^{6}$ Lochmann, E.-R., Naturwiss., 50, 474 (1963).

'Wacker, A., Dellweg, H., and Weinblum, D., Naturwiss., 47, 477 (1960).

\section{BIOLOGY}

\section{Infertility in Mice caused by Nutritional Stress before Mating}

Mice from which all food was withheld for $48 \mathrm{~h}$ from the end of the third to the end of the fifth day after finding copulation plugs did not litter ${ }^{1}$. The fasting appeared to depress hypophyseal gonadotrophic function, causing degeneration of the deciduomata and secondary ombryonic death. Although embryonic death is an important cause of infertility, failure of fertilization and death of ova before nidation are also commonly involved in the pathogenesis of mammalian infertility. This communication reports the results of attempts to influence the viability of the ovum by imposing nutritional stress before ovulation. As it was essential not to inhibit cestrus and mating a shorter period of starvation was given.

In a series of 5 experiments, 8-12-week-old virgin mice of the Sydney White strain were caged in groups of 2,3

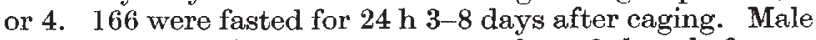
mice were introduced, one per cage from 3 days before to 3 days after the fasting period. 61 comparable mice were not fasted and were kept as controls and were mated at a similar time after caging the females. Water was always 